\title{
Interactions between Kaolinite and Molybdenite in Fresh and Seawater
}

ISSN: 2578-0255

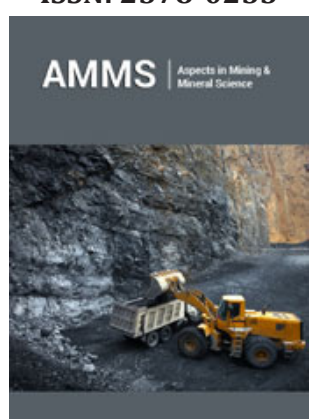

*Corresponding author: Leopoldo Gutiérrez, Department of Metallurgical Engineering, Universidad de Concepcion, Edmundo Larenas 285, Concepcion, Chile

Submission: 監 August 07, 2019

Published: 噠October 17, 2019

Volume 3 - Issue 5

How to cite this article: Leopoldo G Andrés R. Interactions between Kaolinite and Molybdenite in Fresh and Seawater. Aspects Min Miner Sci.3(5). AMMS.000575.2019.

DOI: 10.31031/AMMS.2019.03.000575

Copyright@ Leopoldo Gutiérrez, This article is distributed under the terms of the Creative Commons Attribution 4.0 International License, which permits unrestricted use and redistribution provided that the original author and source are credited.

\section{Leopoldo Gutiérrez* and Andrés Ramírez}

Department of Metallurgical Engineering, Universidad de Concepcion, Edmundo Larenas 285, Concepcion, Chile

\begin{abstract}
Scarcity of fresh water, particularly for operations situated in desert areas, has forced the coppermolybdenum mining companies to look for new sources of water such as seawater. The use of this saline aqueous medium in the process of flotation leads to some important effects on the efficiency of this process. Besides, copper grades of large copper deposits have constantly decreased during the last decades, which is typically associated to high concentrations of clay minerals in the ores which is known to negatively affect the flotation process. The objective of this research was to evaluate the effect of kaolinite on the floatability of molybdenite at different $\mathrm{pH}$ conditions, using two types of solutions $(0.01 \mathrm{M}$ $\mathrm{NaCl}$ solution and seawater). Floatability of molybdenite particles was assessed through micro-flotation tests in a $150 \mathrm{~cm}^{3}$ Partridge-Smith glass cell and using nitrogen $\left(\mathrm{N}_{2}\right)$ at a flowrate of $20 \mathrm{~cm}^{3} / \mathrm{min}$, for a total flotation time of 10 minutes. Flotation feed was prepared mixing known amounts of molybdenite with particles of kaolinite. The results of this study indicate that molybdenite floatability slightly decreased under the presence of fine particles of kaolinite when conventional water was used in the tests. However, in seawater the negative effect of kaolinite was more relevant, in particular at $\mathrm{pH}>9$, which suggests that the presence of cations in solution intensify the phenomenon of heterocoagulation between fine kaolinite particles and molybdenite (slime coating). It is assumed that the stronger depressing effect of kaolinite at $\mathrm{pH}>9$ could be related to the formation of hydroxy-complexes of magnesium and calcium.
\end{abstract}

\section{Introduction}

Molybdenite $\left(\mathrm{MoS}_{2}\right)$ is the primary source of molybdenum. From a structural point of view, molybdenite particles are formed by crystal layers of S-Mo-S which are held together by the action of strong covalent bonds. The interaction between each of these S-Mo-S crystals occurs through the S-S planes (Figure 1), and the process of breakage of the molybdenite particles occurs along these planes. As a result, a non-polar and highly hydrophobic surface which is usually referred to as face, is created. Consequently, molybdenite particles are usually described as anisotropic entities with hydrophobic faces and hydrophilic edges [2]. It is known that the zeta potential of molybdenite particles is the lowest at $\mathrm{pH}$ values ranging between 5.5 and 6.5, which is in agreement with the range of maximum floatability [2]. Regarding the interaction between molybdenite and gangue particles, previous studies showed that the presence of $\mathrm{Ca}^{2+}$ ions in solution induces heterocoagulation between silica and molybdenite which explains the low molybdenum recoveries observed under these conditions $[3,4]$. The negative effect of silica on the floatability of molybdenite was assumed to be related to a phenomenon of slime coatings [4].

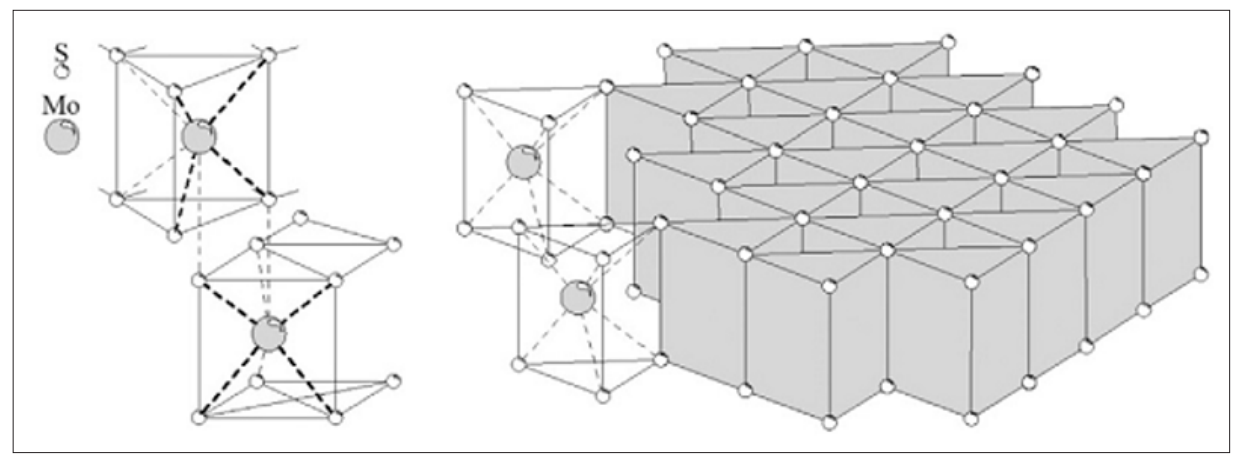

Figure 1: Crystalline structure of molybdenite Castro et al. [1]. 
Molybdenite is commonly associate with copper. The grades of copper-molybdenum deposits in the world have declined, which is typically associated with high concentrations of phyllosilicates, with the clay minerals being the most abundant group. These types of mineral species are usually dispersed in mineral slurries as fine particles, which generates the conditions for non-Newtonian behavior [5]. These characteristics affect the entire mineral processing chain, i.e., milling, froth flotation, thickening, and dewatering [6-12]. The efficiency of the froth flotation process can be severely affected by the presence of high contents of phyllosilicates, and in many cases this problem can be dealt with successfully by diluting the slurry, blending different ore types, and sometimes even disposing of the problematic ores which inevitably leads to losses of valuable minerals [13]. In particular, clay minerals are the most common phyllosilicates found in copper ores and kaolinite is one of the most abundant species [14]. From the surface chemistry point of view, kaolinite has two different surfaces generated during particle breakage, i.e., the basal silica-like and the alumina-like faces $[15,16]$. The silica-like faces carry a negative charge while the alumina-like displays a $\mathrm{pH}$ dependent surface charge resulting from protonation/deprotonation of exposed hydroxyl groups with IEP values around 7.0 [17]. Some studies also suggested that the silica-like faces display hydrophobicity and that dispersion of kaolinite particles in water is explained by the presence of surface imperfections on the faces which create polar micro-edges $[18,19]$. The anisotropic behavior of clay minerals promotes the attachment of these fine particles to minerals (slime coating), and their interactions with reagent and bubbles. All these phenomena reduce the copper and molybdenum floatability and hence recovery $[6,13,20,21]$, and cause major changes in the rheological behavior of mineral slurries [22].

Nowadays, water is a critical and scarce resource for the mining industry and the use of seawater to process copper-molybdenum ores by flotation seems to be a sustainable solution in zones with restricted resources of fresh water such as northern Chile [23]. Seawater contains significant concentrations of different ions $\left(\mathrm{Na}^{+}\right.$, $\mathrm{K}^{+}, \mathrm{Mg}^{2+}, \mathrm{Ca}^{2+}, \mathrm{SO}_{4}^{2-}, \mathrm{Cl}^{-}$) which can potentially adsorb on the solid surfaces and induce heterocoagulation between molybdenite and clay minerals. Earlier publications from the CRHIAM Center of the University of Concepcion, on flotation of $\mathrm{Cu}$-Mo sulfide ores in seawater $[23,24]$ indicated that molybdenite flotation is strongly affected in seawater when $\mathrm{pH}$ is raised with lime to depress pyrite, which is related to the depressing effect of $\mathrm{Mg}^{2+}$ and $\mathrm{Ca}^{2+}$ hydrolysis products on the hydrophobicity of molybdenite. These studies showed that molybdenite floatability can be severely depressed by the action of the products of magnesium hydrolysis, in particular $\mathrm{Mg}(\mathrm{OH})_{2}$, and that in the case of $\mathrm{Ca}^{2+}$ the depressing action can be related to the action of $\mathrm{Ca}(\mathrm{OH})^{+}$. Recently Uribe et al. [22] showed that the depressing effect of kaolinite on chalcopyrite may be related to the formation of hydrolyzed species of calcium and magnesium which can induce heterocoagulation between kaolinite and chalcopyrite (slime coating). Liu et al. [10] also showed that calcium enhanced heterocoagulation between montmorillonite and bitumen can lead to low bitumen recoveries. The objective of this investigation was to evaluate the depressing effect of kaolinite on the floatability of molybdenite using two types of solutions, i.e., a $0.01 \mathrm{M} \mathrm{NaCl}$ solution, seawater, and solutions containing $\mathrm{Ca}^{2+}, \mathrm{Mg}^{2+}$, $\mathrm{Na}^{+}$, and $\mathrm{K}^{+}$at the concentrations at which they appear in seawater, over the $\mathrm{pH}$ range from 8 to 11 .

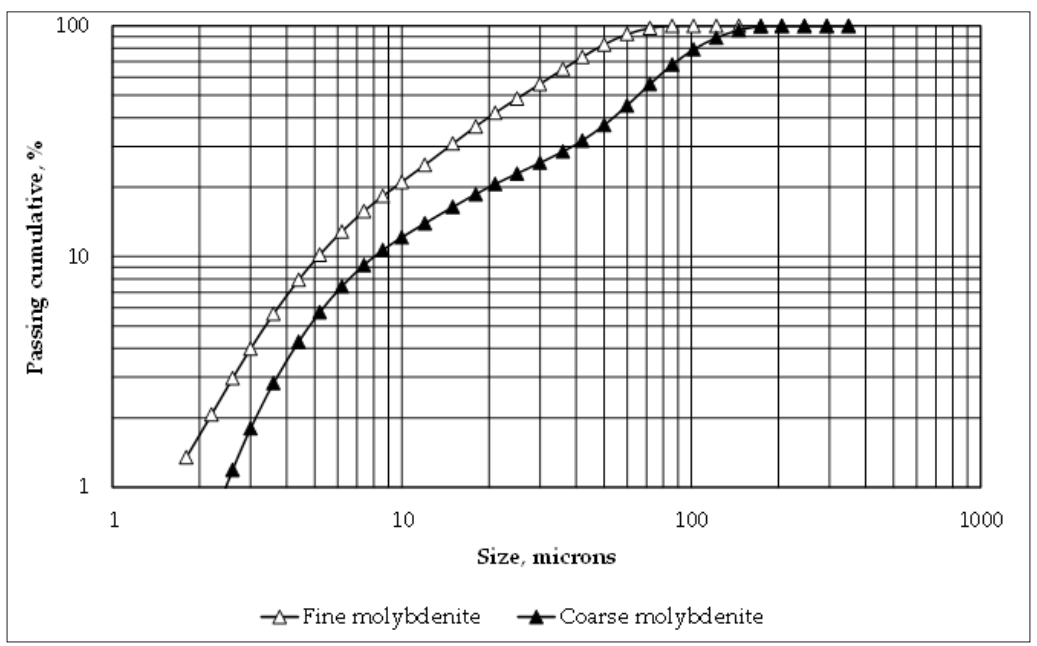

Figure 2: Particle size distribution of molybdenite samples.

\section{Methodology}

\section{Samples and reagents}

The kaolinite sample was provided by the Clay Minerals Society Source clays. XRD analyses (Bruker D4-Endeavor operated with Nifiltered $\mathrm{Cu}$ radiation) indicated that the sample had 96\% kaolinite, $3 \%$ anatase, and $1 \%$ of other traces. Cation exchange capacity (CEC) and Brunauer-Emmett-Teller (BET) surface area were $0.7 \mathrm{cmol} / \mathrm{kg}$ and $180 \mathrm{~m}^{2} / \mathrm{g}$ respectively. The molybdenite sample used in this work was obtained from an industrial molybdenum concentrate, and further purified through 3 stages of flotation without collector. Samples of two particle size distributions were used in this research, i.e., coarse and fine samples. The coarse sample with a P80 of 100 microns corresponded to the original molybdenite samples obtained from the process of purification, while the fine sample with a P80 of 50 microns was obtained by hand grinding the 
coarse sample. Figure 2 shows the particle size distributions. The samples were then washed and cleaned following the procedure described by Uribe et al. [22] which considers 3 stages of washing with sodium hydrosulfide ( $\mathrm{NaSH}$ ) and acetone in order to remove any organic reagents such as collectors present in the sample. Table 1 shows the chemical analysis of the samples. In order to keep molybdenite oxidation at minimum, the samples were stored in a freezer in sealed plastic bags previously blown with nitrogen, at a temperature of about $1{ }^{\circ} \mathrm{C}$ [25-27].

Table 1: Chemical analyses of molybdenite samples.

\begin{tabular}{|c|c|c|c|c|c|}
\hline \multicolumn{7}{|c|}{ Chemical Analyses in XRD } \\
\hline Sample & Cu(\%) & Fe(\%) & S(\%) & Mo(\%) & Ins(\%) \\
\hline Coarse & 0.55 & 0.49 & 37.9 & 55.4 & 5.3 \\
\hline Fine & 0.53 & 0.39 & 38.0 & 55.8 & 5.1 \\
\hline
\end{tabular}

Methyl Isobutyl Carbinol (MIBC) of analytical grade was used as frother at $15 \mathrm{ppm}$, and potassium amyl xanthate (PAX) as collector at $25 \mathrm{ppm}$ for the micro-flotation tests. It has to be noted that PAX was purified by dissolution in acetone, and precipitated with ether. Analytical grade $\mathrm{NaCl}, \mathrm{KCl}, \mathrm{MgCl}_{2}$ and $\mathrm{CaCl}_{2}$ (Merck) were used to prepare the solutions. Distilled water with an electrical conductivity of $21.5 \mu \mathrm{S} / \mathrm{cm}$ was used in all the experiments. Seawater samples were taken from the Lenga Coast in the VIII Region of Bio in Chile. The $\mathrm{pH}$ was adjusted with sodium hydroxide and hydrochloric acid (Merck).

\section{Micro flotation}

The floatability of molybdenite was evaluated through microflotation tests that were carried out in a $150 \mathrm{~mL}$ Patridge and Smith glass cell using nitrogen $\left(\mathrm{N}_{2}\right)$ at a flowrate of $80 \mathrm{~mL} / \mathrm{min}$ (Figure 3 ). The flotation feed was prepared by mixing $1 \mathrm{~g}$ of molybdenite (coarse and fine) with $0.15 \mathrm{~g}$ of kaolinite to then prepare a suspension using $100 \mathrm{~mL}$ of solution $(0.01 \mathrm{M} \mathrm{NaCl}$ or seawater). After 3 minutes of conditioning at the required $\mathrm{pH}, \mathrm{MIBC}$ and PAX were added at a concentration of $15 \mathrm{ppm}$ and $25 \mathrm{ppm}$ respectively (based on the $150 \mathrm{~mL}$ of the micro-flotation cell) and conditioned for 5 more minutes at the previously established $\mathrm{pH}$ value. Additional solution was then added to complete the $150 \mathrm{~mL}$ required for the microflotation glass cell. Finally, the gas valve was opened to start the process of flotation, which was carried out for 3 minutes, pulling froth every 10 seconds. Pulp level in the micro-flotation cell was kept constant by adding a background solution prepared at the same composition and $\mathrm{pH}$ of the original solution. Finally, in order to separate molybdenite and kaolinite particles, the concentrates and tailings were sieved using a 400\# screen (38 microns) and dried in an oven at $105{ }^{\circ} \mathrm{C}$ for 5 hours. This way it was possible to measure the mass of molybdenite in the concentrate, and the solids flotation yield was calculated as the ratio between the mass of molybdenite in the concentrate and the mass of molybdenite in the concentrate tailings. All testing was done in duplicate.

\section{Induction time measurements}

Induction time measurements were conducted using the procedure described by Castro et al. [24] and the induction time meter built at the University of Alberta. According to this procedure, a fresh bubble held on a capillary is pushed downward through a solution so that it is kept in contact with a bed of particles for a measured and controlled contact time span. Then, the bubble is lifted upwards to its initial position and observed through a microscope in order to determine whether attachment occurred during the contact period or not. The process is repeated 10 times at different positions on the particle bed and the number/ percentage of successful contacts is determined. Then, the contact time is changed to different values and the procedure is repeated again in each case. The final result of the test is a plot of percentages of successful contacts (Nsc) versus the measured contact time (tc). In this work, the induction time was obtained by determining the contact time at which $50 \%$ of the contacts were successful. The experimental data were fitted using Equation 1.

The beds of particles were prepared by mixing 3 grams of molybdenite (for size) with $30 \mathrm{~mL}$ of solution containing $40 \mathrm{ppm}$ of PAX. Immediately after, fine particles of kaolinite were added at a concentration of $13 \%$ (solid base). Then, the $\mathrm{pH}$ was adjusted to the required value and the slurry was conditioned for 12 minutes, after which it was transferred to a $15 \mathrm{~mL}$ cell in order to start the induction time measurements. It has to be pointed out that no frothier was added in these experiments and that air was used to generate the bubbles. All these experiments were conducted in duplicate thus the results presented in this paper are average values. It has to be noted that these types of measurements were previously used to evaluate the effect of slime coating on the floatability of molybdenite in the presence of clay minerals [28] and different ions.

\section{Results and Discussion}

\section{Micro flotation}

Figure 3 shows the recovery of coarse molybdenite in $0,01 \mathrm{M}$ $\mathrm{NaCl}$ solution and in seawater, in the presence and absence of kaolinite. The results indicate that the effect of kaolinite on the floatability of molybdenite at the whole range of $\mathrm{pH}$ is minor when the process of flotation is carried out using a $0.01 \mathrm{M} \mathrm{NaCl}$ solution. In contrast, in seawater the effect of kaolinite on molybdenite recovery seems to be stronger, in particular at $\mathrm{pH}>9$. In other words, the depressing effect of kaolinite seems to be important only in an aqueous media of high ionic strength such as seawater. The theory of stability of colloidal systems developed by DerjaguinLandau-Verwey-Overbeek (DLVO) can be used to better understand the interactions between kaolinite and molybdenite. The DLVO theory considers the existence of two forces that affect the process of aggregation of colloidal particles, i.e., van der Waals forces of attraction and repulsive forces generated by the interactions of the electrical double layers. Thus, to explain the results presented in Figure 3, it is necessary to analyze the effect of $\mathrm{pH}$ on the surface charge of both minerals. The surfaces of the faces and edges of molybdenite particles are expected to be negatively charged at $\mathrm{pH}$ values between 7 and 11, [2]. Besides, previous studies reported that the surface charge of the alumina-like faces of kaolinite becomes close to zero at $\mathrm{pH}$ values around 7-8 [15,16]. Then, according 
to this information heterocoagulation between kaolinite and molybdenite should be more likely at lower $\mathrm{pH}$, however the data presented in Figure 3 indicate that there is not a clear correlation between $\mathrm{pH}$ and the depressing effect of kaolinite on the floatability of molybdenite which suggests no heterocoagulation.

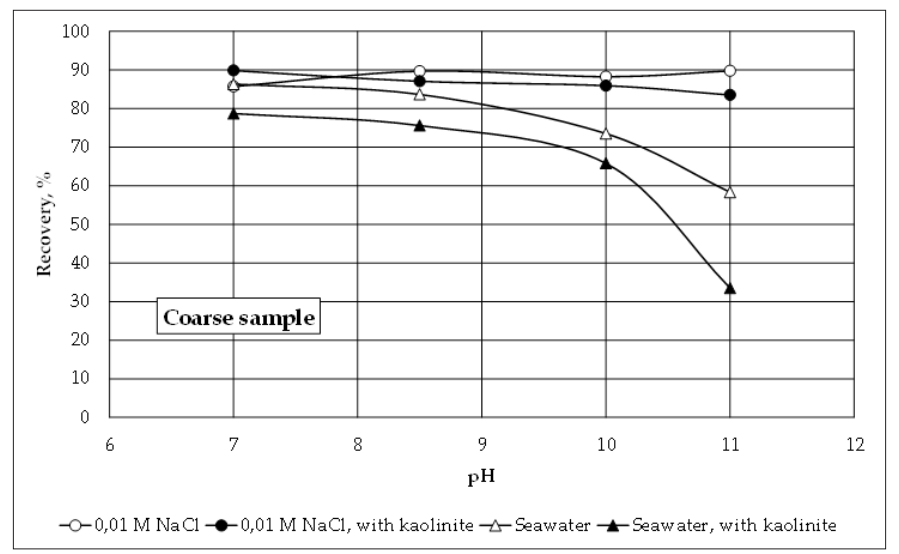

Figure 3: Recovery of coarse molybdenite using conventional and seawater with and without kaolinite.

When looking at the results for seawater in Figure 3, it can be seen that the effect of kaolinite is more significant in seawater than in fresh water at the whole range of $\mathrm{pH}$, but at $\mathrm{pH}>9$ the depressing effect of kaolinite becomes more important. The fact that the $\mathrm{pH}$ value at which the trend changes is 9 , suggests that the stronger depressing effect of kaolinite observed at this $\mathrm{pH}$ range is related to the formation of hydroxy-complexes of magnesium and calcium and their influence on the interactions between kaolinite and molybdenite. Previous studies showed that the first hydroxycomplex of magnesium $\mathrm{Mg}(\mathrm{OH})^{+}$starts forming at $\mathrm{pH}$ 9, reaching a maximum concentration at $\mathrm{pH}$ 10.5. At this $\mathrm{pH}$, positively charged precipitates of $\mathrm{Mg}(\mathrm{OH})_{2(\mathrm{~s})}$ can also form which can affect the properties of the air/liquid and solid/liquid interfaces. In the case of calcium, the first hydroxy-complex $\mathrm{Ca}(\mathrm{OH})^{+}$forms around pH 9.5-10 with the maximum concentration obtained at $\mathrm{pH}$ values around 13-13.5. The presence of these hydroxy-complexes seems to enhance the interactions between clay particles and molybdenite, phenomenon referred to as "slime coating". The induction time is the time required to break the liquid film existing between a bubble and a particle after the two collide. Therefore, high induction time values indicate that the particle-bubble adhesion is favorable and therefore, better molybdenite recoveries should be expected. Figure 4 shows the induction time data obtained using coarse molybdenite in conventional and seawater, and with and without kaolinite. The results of induction time are in good agreement with the micro-flotation data. Firstly, it can be seen that in general the induction time values are higher in the presence of kaolinite in both fresh and seawater. Additionally, the depressing effect of kaolinite is more important in seawater, in particular at $\mathrm{pH}>9$, which is again in perfect agreement with the data of micro-flotation. Therefore, the induction time results validate the conclusions obtained in the micro-flotation testing.

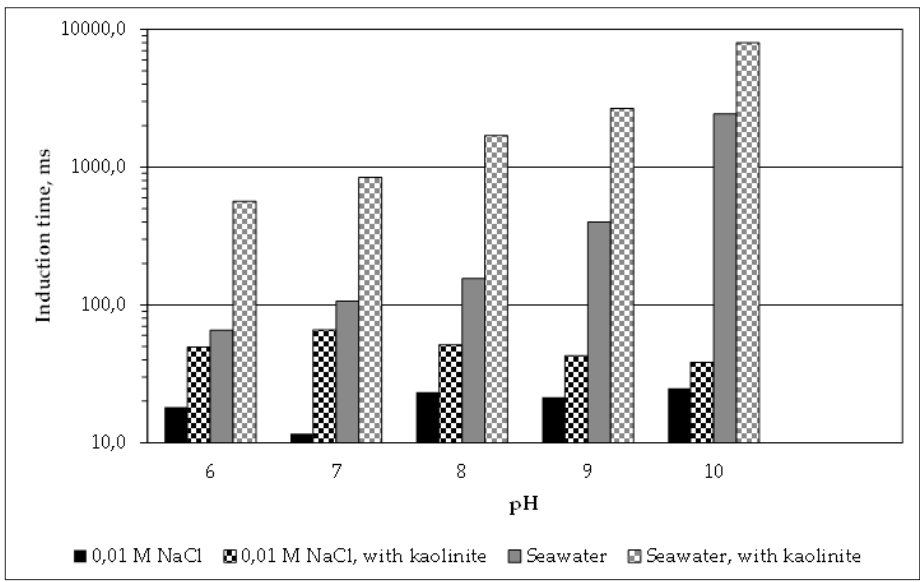

Figure 4: Induction time of fine molybdenite using conventional and seawater with and without kaolinite.

Figure 5 shows the recovery of fine molybdenite using conventional and seawater, with and without kaolinite. The first observation that can be made is that in general the recovery values obtained in a $0.01 \mathrm{NaCl}$ solution using the fine molybdenite sample tend to be lower than those obtained with the coarse sample.
This is also observed in the results obtained using seawater at pH 7-9. This can be related to the fact that the face/edge ratio decreases with particle size, which has an effect on hydrophobicity leading to low values of recoveries. However, when comparing the recovery of molybdenite at $\mathrm{pH}>9$, it can be seen that the 
depressing effect of kaolinite is more important on coarse particles of molybdenite. As was previously explained, formation of hydroxycomplexes of magnesium and calcium at $\mathrm{pH}>9$ seems to enhance heterocoagulation between kaolinite and molybdenite and the results presented in (Figure $3 \& 5$ ) indicate that this phenomenon is more relevant on coarse particles. The presence of hydroxycomplexes of magnesium and calcium can induce attachment of kaolinite to the faces and edges of molybdenite through a mechanism of surface charge neutralization. As the face/edge ratio is higher for coarse particles, heterocoagulation between kaolinite and the molybdenite faces is more likely in this case, and that could explained why kaolinite affects more the recovery of coarse molybdenite at $\mathrm{pH}>9$.

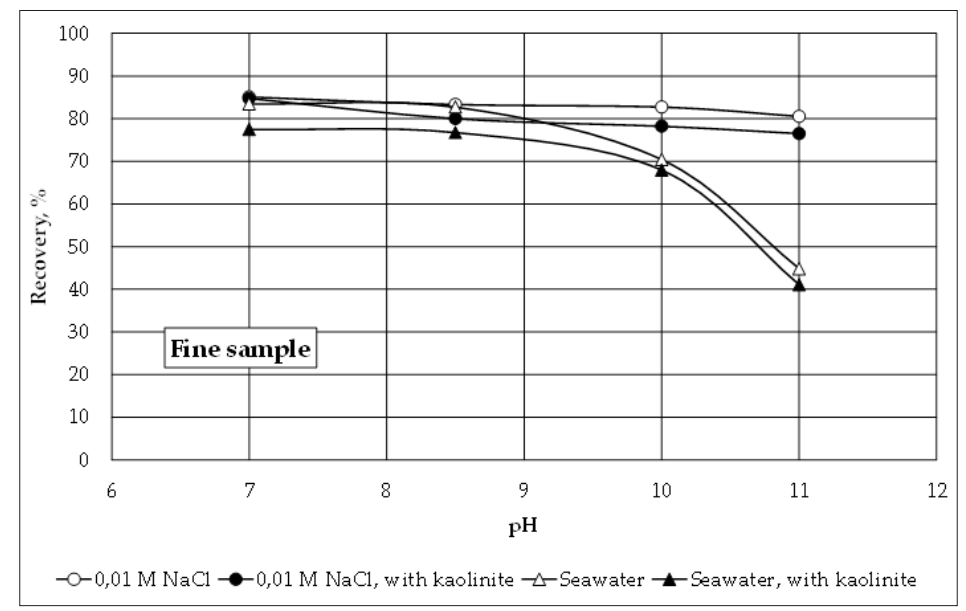

Figure 5: Recovery of fine molybdenite using conventional and seawater with and without kaolinite.

\section{Conclusion}

The depressing effect of kaolinite on the floatability of molybdenite at $\mathrm{pH}$ values between 7 and 11 is less important when the process of flotation is carried out using a $0.01 \mathrm{M} \mathrm{NaCl}$. In seawater the depressing effect of kaolinite seems to be stronger, in particular at $\mathrm{pH}>9$. The fact that the $\mathrm{pH}$ value at which the trend changes is 9 , suggests that the stronger depressing effect of kaolinite observed at this $\mathrm{pH}$ range can be related to the formation of hydroxy-complexes of magnesium and calcium and their influence on the interactions between kaolinite and molybdenite. Hydroxy-complexes of magnesium and calcium can induce attachment of kaolinite to the faces and edges of molybdenite through a mechanism of surface charge neutralization [1,29]. As the face/edge ratio increases with particle size, heterocoagulation between kaolinite and molybdenite faces is more likely for coarse sizes, and that could explain why kaolinite affects more the recovery of coarse molybdenite at $\mathrm{pH}>9$. These conclusions were validated through induction time measurements.

\section{Acknowledgement}

The support from the National Fund for Scientific and Technological Development(FONDECYT) of Chile under the projects initiation into research no. 11140184, and Centro CRHIAM Proyecto CONICYT/FONDAP/15130015, is gratefully acknowledged.

\section{References}

1. Castro S, Lopez Valdivieso A, Laskowski JS (2016) Review of the flotation of molybdenite. Part I: Surface properties and floatability. International Journal of Mineral Processing 148: 48-58.

2. Chander S, Fuerstenau DW (1972) On the natural floatability of molybdenite. Transactions of AIME 252: 62-69.
3. Tabares J, Madrid I, Reyes J, Sánchez A, Valdez D, et al. (2006) Surface properties and floatability of molybdenite. Proceedings of 2006 ChinaMexico Workshop on Minerals Particle Technology, Mexico, pp. 115-124.

4. Raghavan S, Hsu LL (1984) Factors affecting the flotation recovery of molybdenite from porphyry copper ores. International Journal of Mineral Processing 12(1-3): 145-162.

5. Bakker CW, Meyer CJ, Deglon DA (2009) Numerical modelling of nonnewtonian slurry in a mechanical flotation cell. Minerals Engineering 22(11): 944-950.

6. Ndlovu B, Forbes E, Farrokhpay S, Becker M, Bradshaw D, et al. (2014) A preliminary rheological classification of phyllosilicate group minerals. Minerals Engineering 55: 190-200.

7. Ndlovu B, Farrokhpay S, Bradshaw D (2013) The effect of phyllosilicate minerals on mineral processing industry. International Journal of Mineral Processing 125: 149-156.

8. Ralston J, Fornasiero D, Grano S, Duan J, Akroyd T (2007) Reducing uncertainty in mineral flotation-flotation rate constant prediction for particles in an operating plant ore. International Journal of Mineral Processing 84(1-4): 89-98.

9. He M, Wang Y, Forssberg E (2004) Slurry rheology in wet ultrafine grinding of industrial minerals: A review. Powder Technol 147(1-3): 94112.

10. Liu J, Zhou Z, Xu Z, Masliyah J (2002) Bitumen-clay interactions in aqueous media studied by zeta potential distribution measurement. Journal of Colloid and Interface Science 252(2): 409-418.

11. McFarlane AJ, Addai Mensah J, Bremmell K (2005) Microstructure, rheology and dewatering behavior of smectite dispersions during orthokinetic flocculation. Minerals Engineering 18(12): 1173-1182.

12. Melipichun C, Gutierrez L (2014) Influence of clays on induction time, floatability and foam stability in the process of flotation of copper sulphide minerals. XXVII International Mineral Processing Congress Chile, pp. 1-9.

13. Connelly D (2011) High clay ores-A mineral processing nightmare Part 2. In: Australian. Bulk Handling Review: 78-81. 
14. Kelm U, Helle S, Jerez O, Pincheira M (2013) What are copper clays? Geometallurgical implications. Copper international Conference (COPPER 2013) Chile, pp. 257-266.

15. Laskowski JS (2010) Rheological properties of aqueous suspensions of anisotropic minerals. In: Rheology and Processing of Fine Particles Proceedings of the $8^{\text {th }}$ UBC-McGill-UA International Symposium on Fundamentals of Mineral Processing, Canada, pp. 137-157.

16. Laskowski JS (2012) Anisotropic minerals in flotation circuits. Canadian mineral processing CIM Journal 3(4): 203-213.

17. Johnson SB, Russell AS, Scales PJ (1998) Volume fraction effects in shear rheology and electroacoustic studies of concentrated alumina and kaolin suspensions. Colloids and Surfaces A: Physicochem and Engineering Aspects 141(1): 119-130.

18. Saada A, Siffert B, Papier E (1995) Comparison of the hydrophilicity/ hydrophobicity of illites and kaolinites. Journal of Colloid and Interface Science 174(1): 185-190.

19. Miller JD, Nalaskowski J, Abdul B, Du H (2007) Surface characteristics of kaolinite and other selected two-layer silicate minerals. The Canadian Journal of Chemical Engineering 85(5): 617-624.

20. Ralston J, Fornasiero D, Hayes R (1999) Bubble-particle attachment and detachment in flotation. International Journal of Mineral Processing 56(1-4): 133-164.

21. Forbes E, Davey KJ, Smith L (2014) Decoupling rehology and slime coatings effect on the natural flotability of chalcopyrite in a clay-rich flotation pulp. Minerals Engineering 56:136-144.
22. Uribe L, Gutierrez L, Jerez O (2016) The depressing effect of clay minerals on the floatability of chalcopyrite. Mineral Processing and Extractive Metallurgy Review 37(4): 227-235.

23. Castro S, Rioseco P, Laskowski JS (2012) Depression of molybdenite in sea water. XXVI International Mineral Processing Congress-IMPC India, pp. 737-752.

24. Castro S, Uribe L, Laskowski JS (2014) Depression of inherently hydrophobic minerals by hydrolysable metal cations: molybdenite depression in seawater. XXVII International Mineral Processing Congress-IMPC, Chile, pp. 207-217.

25. Ekmekci Z, Demirel H (1997) Effects of galvanic interaction on collectorless flotation behaviour of chalcopyrite and pyrite. International Journal of Mineral Processing 52(1): 31-48.

26. Zhang Q, Xu Z, Bozkurt V, Finch JA (1997) Pyrite flotation in the presence of metal ions and sphalerite. International Journal of Mineral Processing 52(2-3): 187-201.

27. Ansari A, Pawlik M (2007) Floatability of chalcopyrite and molybdenite in the presence of lignosulfonates. Part I. adsorption studies. Minerals Engineering 20(6): 600-608.

28. Oats WJ, Ozdemir 0, Nguyen AV (2010) Effect of mechanical and chemical clay removals by hydro-cyclone and dispersants on coal flotation. Minerals Engineering 23(5): 413-419.

29. Liu J, Xu Z, Masliyah J (2004) Role of fine clays in bitumen extraction from oil sands. AIChE Journal 50(8): 1917-1927. 